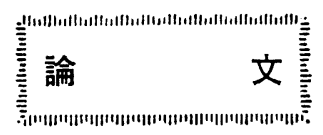

\title{
ガラス管の外面に紫外線吸収膜を 塗布した蛍光ランプ
}

\author{
正会員 田屋 明* 正会員 新羅 久美** \\ 高柳 敬志***宮崎 信幸***

\section{Fluorescent Lamp with a UV-absorption Film Coated Outside the Glass Tube}

\author{
Akira Taya (Member) \\ (Researct \& Development Center, Toshiba Corporation) \\ Hisami Nira (Member) \\ (Lightig Engineering Division, Toshiba Corporation) \\ Takashi Takayanagi and Nobuyuki Miyazaki \\ (Research \& Development Division, Asahi Glass CO., LTD)
}

\begin{abstract}
The light emitted from the conventional fluorescent lamps contains a small amount of ultraviolet (UV) radiation, which causes color change or bleaching of the illuminated objects. Thus, in the presence of paintings and printed matters, application is made of the UV-free fluorescent lamps with a UV-absorption layer deposited in- or outside of the glass tube. However, the UV-absorbing materials employed so far have been fast-deteriorating, and made luminous flux or color rendering properties inferior to the lamps without the absorption layer.

By applying outside the tube a solvent-soluble fluororesin containing a UV-absorbing substance, a UV-free fluorescent lamp is obtained without the above mentioned disadvantages.
\end{abstract}

\section{1. ま え がき}

通常の虽光ランプの光の中には少量の紫外線が含まれており， これが被照射体の変色や退色を引き起こす。そのため, 絵画や印 刷物または商品価值の高いものなどの照明には, 無紫外線絈光ラ ンプ（以下，NU ランプと呼ぶ）が使用されている.

NU ランプには, (1)ガラス管の内面に紫外線を吸収する酸化チ タン $\left(\mathrm{TiO}_{2}\right)$ を塗布し，その上に蛍光体層を形成したもの主およ び，(2)紫外線吸収剂を含も樹脂をガラス管の外面に叙布したもの がある ${ }^{233)}$. しかし， 前者は紫外線の遮断に伴い全光束や演色性 などのランプ特性がある程度犠牲になり，また後者は耐候性およ び耐久性などの点で必ずしも満足できるものではなかった．

われわれは，後者の方法によるNU ランプに注目し耐候性およ び而久性の優れた樹脂について検討し，溶剤可溶形ふっ素樹脂4

\footnotetext{
* 榯東芝総合研究所

平210 川崎市幸区小向東艺町 1

1 Komukai Toshibacho, Saiwai-ku, Kawasakishi, Kanagawa 210 Japan

** 椎東芝照明技術部

空237 横得賀市船越町 1-201-1

201-1 Funakoshicho 1, Yokosukashi, Kanagawa 237 Japan

*** 旭硝子陎研究開発部玉川分室牙210 川崎市幸区塚越 3-474-2

474-2 Tsukakoshi 3, Saiwai-ku, Kawasakishi, Kanagawa 210 Japan

本論文の一部は，筆者らが昭和60年度第18回照明学会全国大会で講演したもので ある.
}

を取り上げ NU ランプヘの適用を試みた.

以下，この樹脂の特性およびこの樹脂を用いた NU ランプの 特性について報告する.

\section{2. 溶剤可溶形ふっ素樹脂}

\section{1 基本分子構造}

従来のふっ素樹脂は耐久性, 耐薬品性, 耐熱性に優れている. 一方, 融点が高く, 溶剤に溶けにくく, さらに透明性が低く, 基 材への密着性が悪いなどと,コーティング用樹脂として重大な欠 点を有していた. 最近開発された溶剂可溶形塗料用ふっ素樹脂4) （以下，LF 樹脂と呼ぶ）は，図１に示すようなフロロオレフィ ンとビニルェーテルモノマーとの完全な交互共重合体を基本骨格 とする分子構造を有する新しい含ふっ素高分子である.

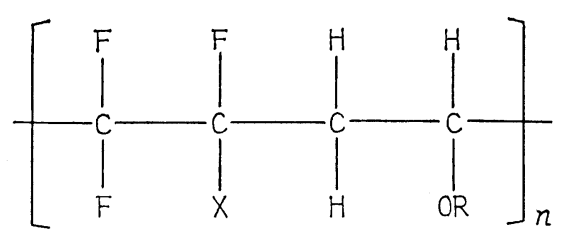

$\mathrm{R}:$ アルキル基 およびその誘:苄体

图 1 LF 樹脂の基本分子構造 


\section{2 基 本 物 性}

LF 樹脂の基本物性を表 1 に示す. LF 樹脂は $45 \sim 50^{\circ} \mathrm{C}$ にカ ラス転移点をもつ透明な非晶性ポリマーで, そのふっ素含有量は 25〜30 wt\%である. また, 側鎖の $\mathrm{OH}$ 基㗎橋剤を反応させる ことにより，溶剂に不溶の強じんな叙膜が得られ，極性の高い $\mathrm{COOH}$ 基によって, 基材への密着性招よび架橋剤との相溶性を向 上させることができる. これらの $\mathrm{OH}$ 基および $\mathrm{COOH}$ 基の含有 量は目的に応じて調節できる。

表 1 LF 樹脂の基本物珄

\begin{tabular}{|c|c|}
\hline 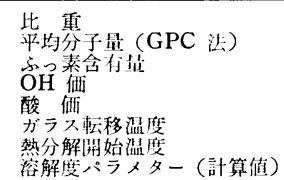 & $\begin{array}{l}1.40 \\
\mathrm{Mn}=20,000, \mathrm{Mw}=50,000 \\
25 \sim 30 \mathrm{wt} \% \\
47 \sim 52 \mathrm{mg} \mathrm{KOH} / \mathrm{g} \\
0 \sim 5 \quad \mathrm{mg} \mathrm{KOH} / \mathrm{g} \\
45 \sim 50^{\circ} \mathrm{C} \\
240 \sim 250^{\circ} \mathrm{C} \\
8.8\end{array}$ \\
\hline
\end{tabular}

\section{3 溶剤への可溶性}

LF 樹脂は, 従来のふっ素樹脂の俊れた特性を儀牲にすること なく, 塗料樹脂としての欠点を解決した溶剤可溶形のふっ素樹脂 で, 芳不族, ケトン，エステル，アルコール系などほとんどすべ ての有機溶剤に溶ける. したがって沉用塗料と同様の施行が可能 である.

\section{3. 樹脂塗膜の特性}

\section{1 耐候性および耐久性}

LF 樹脂塗料を NU ランプに適用した場合, 塗膜は紫外線源の 近傍にあるため，特に高い耐紫外線性を要求される.

この LF 樹脂涂膜と既存の樹脂叙膜の耐候性, おょび耐久性を 比較するために, 集光形促進試験掞よびウェザメータによる促進 曝露試験を行なった.

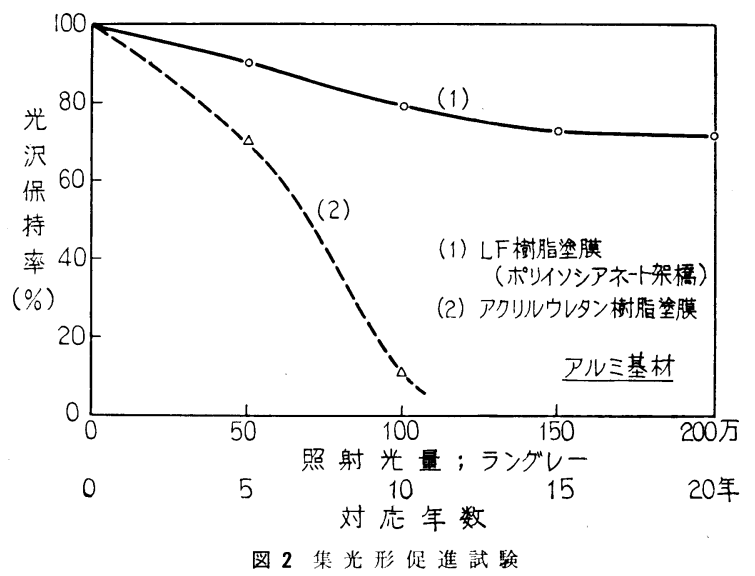

図 2 に集光形促進試験の結果を示す.これは, アリゾナ砂漠 で自然光を集光して照射（横軸の対応年数は東京における年間の 光の総量に換算してある）した場合の塗膜表面の光沢の変化，す なわち光沢保持率*を表わしている.この結果によると，比較的 耐候性が良いとされている市肘のアクリル樹脂塗膜に比べ，LF 樹脂塗膜は, 表面光沢の低下がきわめて小さく劣化の程度に格段 の差がある. 次にウェザメータによる促進暴露試験の結果を図 3 に示す。 上記の試験結果之同様に, 既存の樹脂塗膜に比べ LF 樹 脂塗膜は高い光沢保持率を示し, 劣化しにくいことがわかる.

以上の耐候性試験の結果から明らかなように, LF 樹脂は既存

* 光沢保持率 $=\frac{60^{\circ}-60^{\circ} \text { 鏡面光沢度 (照射後) }}{60^{\circ}-60^{\circ} \text { 鏡面光沢度 (初期值) }} \times 100(\%)$.

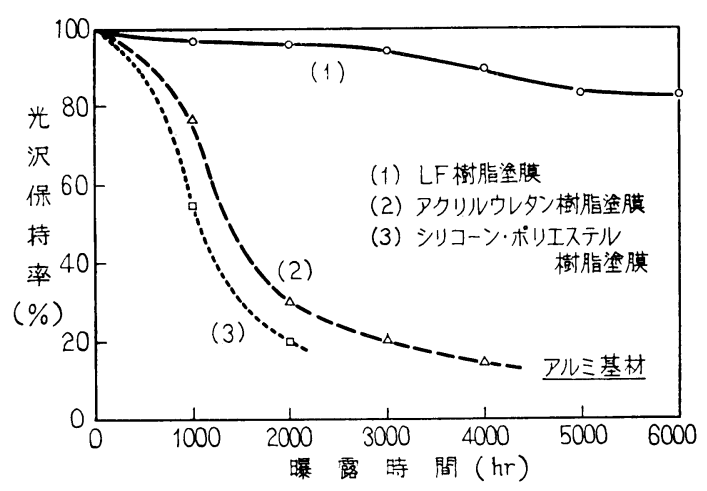

図 3 ウェザメータによる促進曝露陚験;

の高分子材料に見られない高酎候性，すなわち高い耐紫外線性を 有していることがわかる.これは，図 1 に示したよらにビニルェ 一テル単位がフロロオレフィン単位ではさまれており，完全な交 互共重合体であり，このような交互配列によって本来安定なフロ ロオレフィン単位に加えて，ビニルェーテル単位までもその炭 素一荻素あるいは荻素一水素結合を立体的ないし電子的に保護, 強 化し，線外線劣化の原因となるラジカルの発生，および伝播を阻 止するためである.

\section{2 透 明 性}

LF 樹脂塗膜 (膜厚 : $25 \mu \mathrm{m}$ ) の光線透過率を測定したところ, 近紫外から可視領域までの広範囲で高い透過率を示した，その透 過率は可視領域で $90 \%$ ，近紫外領域で70\%以上といら他の樹脂に 見られない優れた透明性である.

\section{3 紫外線の吸収}

LF 樹脂は上記のように, 紫外領域での透過制も高くNU ラン プへの適用にあたっては, ランプより発生する紫外線を吸收, 遮 断する塗膜に変成することが必要である.

まず，紫外線吸収剂として，ベンゾフェノン系，ベンゾトリア ゾール系, サリシレート系, 置換アクリロニトリル系, ニッケル 錯体系, ヒンダートアミン系, 超微粒酸化チタンおよび透明ベン ガラを取り上げ，これらの紫外線の吸収能力，可視領域の光線透 過率，耐熱性および LF 樹脂との相溶性などについて調べた。こ の結果, 上記の条件がすべて満足できるものは, ベンゾフェノン 系とベンゾトリアゾール系の紫外線吸収剤であった.

そこで，この 2 種類の紫外線吸収剂を用いて LF 樹脂の変成を 行なった.

これらの紫外線吸収剂配合の LF 樹脂塗膜をガラス板（厚さ $1.5 \mathrm{~mm}$ ）の上に，膜厚 $25 \mu \mathrm{m}$ となるように形成させた．図 4 に 光線透過率を示す. いずれも可視領域の透過率は高く, ガラス板

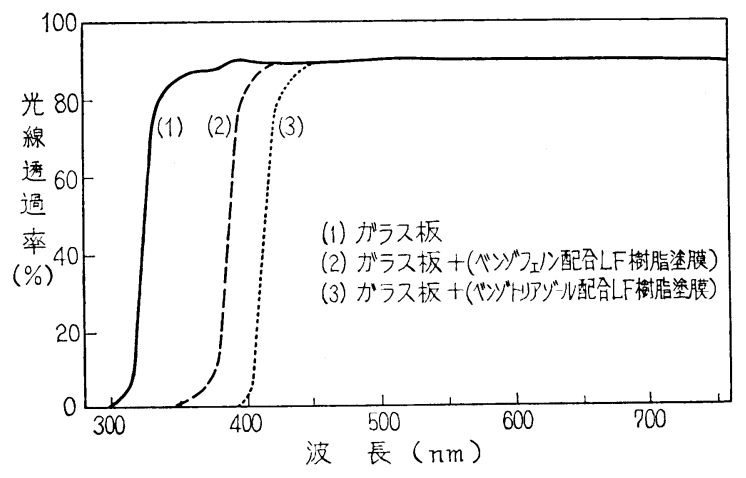

図 4 塗膜の光線透過率 
そのものと全く変わらない，一方，紫外領域ではベンゾフェ， ンを用いたものは $350 \mathrm{~nm}$ ，また，ベンデトリアゾールの洁らは $380 \mathrm{~nm}$ 以下の紫外線を完全に吸収する. 以上の上うな特徴を有 する LF 樹脂を NU ランプに適用した場合について以下に述べ る.

\section{4. 無紫外線 (NU) 蛍光ランプへの適用}

\section{1 供試蛍光ランプ}

ランプ試験は, 直管 $20 \mathrm{~W}$ (FL $20 \mathrm{~S}$ 形) の演色性区分（JIS Z 9112-1983）に扎ける, 普通形（昼光色, D, 以下 D 形ランプと 呼ぶ), 演色 A形 (白色, W-DL, 以下 W-DL 形ランプと呼ぶ), 拈よび演色 AAA 形 (白色, W-EDL, 以下 W-EDL 形ランプと 呼ぶ）に属する試作ランプを用いて行なった。

\section{2 塗膜 の 形成}

上記の蛍光ランプの外面に, 前述の LF 樹脂を主成分とし, 柴 外線吸収剂（ベンゾフェノン拈よびベンゾトリアゾール），特よ び硬化剂（インシアネート）を配合した塗料（溶媒：キシレン） を用いて 図 5 に示すような手順で塗膜を形成した。

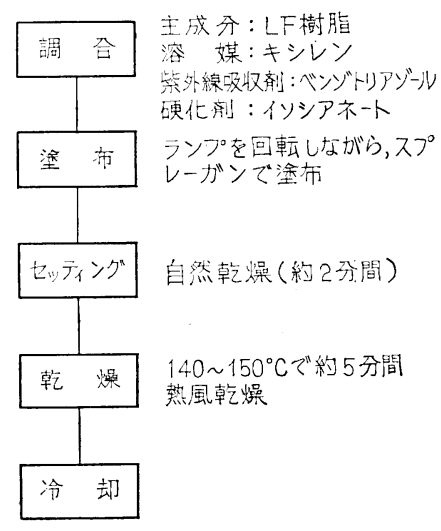

図 5 淘膜の形成方法

LF 樹脂塗料の塗布はスプレーガンを用い, 鸴光ランプを水平 に保ち回転しながら行なった，次いで，ランプを回転させたまま 約 2 分間自然乾燥（セッティング）し， $140 \sim 150^{\circ} \mathrm{C}$ の温度で約 5 分間熱風乾燥した. このようにして得られたランプの LF 樹脂 塗膜の膜厚を測定したところおよそ $25 \mu \mathrm{m}$ であった。

\section{3 分光エネルギー分布}

\section{3.1 紫外線吸収剤による違い}

2 種類の異なる紫外線吸収剂を配合した LF 樹脂塗膜を，D形 ランプの外面に形成した。 これらの蛍光ランプの紫外領域 (300

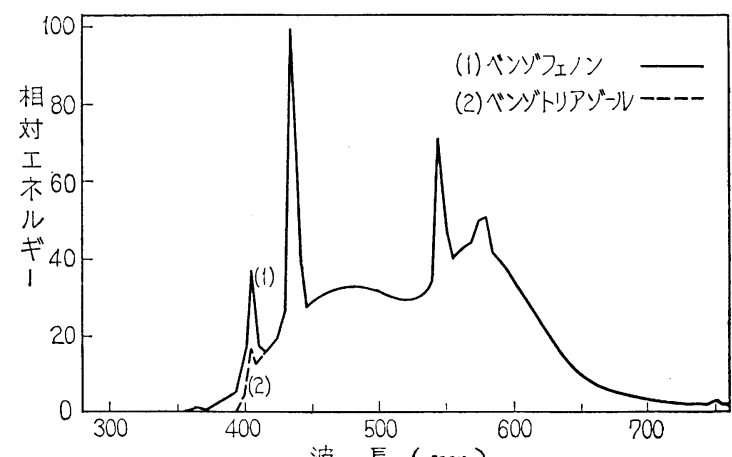

波 長 $(\mathrm{nm})$

图 6 紫外線吸收剂の異なる LF 臌脂叙膜を設けた D形ランブ (FL 20 S) の分光ェネルギー分布 $\mathrm{nm})$ から, 可視領域 $(760 \mathrm{~nm})$ の分光エネルギー分布を図 6 に示す、ベンゾトリアジールを線外線吸収剂として用いたもの は, 313 扣よび $365 \mathrm{~nm}$ の水銀輝線が完全に吸収されているのに対 して, ベンゾフェノンのほうは $365 \mathrm{~nm}$ の水銀輝線スペクトルが ごく少量ではあるが認められる.このため, 紫外線吸収剤として はベンゾトリアゾールを選択し，以下の試験を行なった。

\subsection{2 従来品および通常品との比較}

酸化チタンをランプの内面に塗布した, 従来のランプ（以下, 従来品と呼ぶ), 括よび紫外線吸收膜なしの同種のランプ(以下, 通常品と呼ぶ）と，LF 樹脂塗膜をランプ外面に形成したランプ （以下，開発品と呼ぶ）の分光エネルギ一分布を比較して, 図 7 (D形ランプ), 図 8 (W-DL 形ランプ)扣よび図 9 (W-EDL 形) に示す（な拉, 分光エネルギ一分布は $436 \mathrm{~nm}$ の水銀輝線が 100.0 となるように規格化してある).

まず，柴外領域の分光エネルギー分布を見ると， D形, W-DL

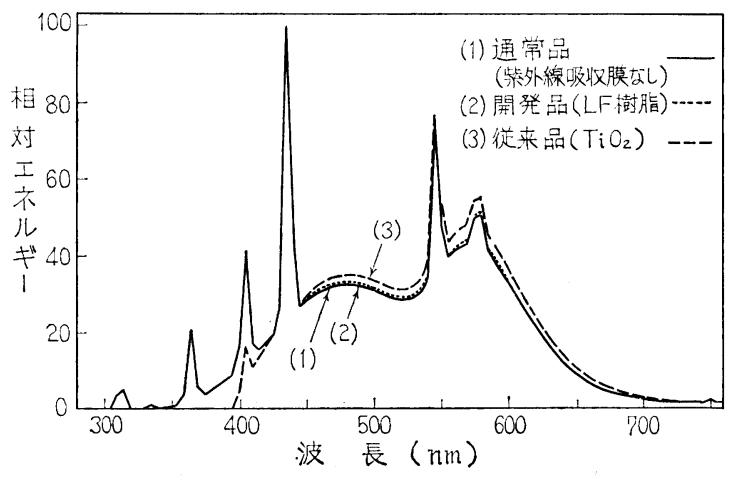

図 7 D 形ランプ (FL 20 S) の分光ェネルギー分布
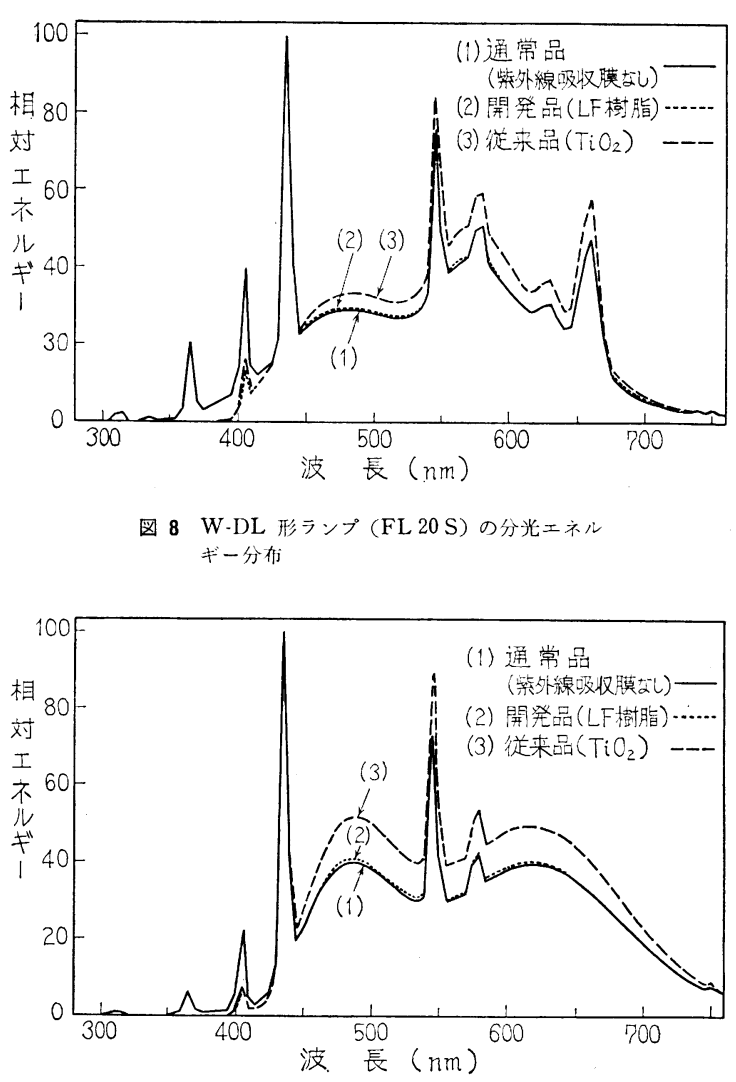

図 9 W-EDL 形ランプ (FL 20S) の分光エネ ルギー分布 
形掞よび W-EDL 形ランプの開発品および従来品は, 通常品に 含まれている $313 \mathrm{~nm}$, および $365 \mathrm{~nm}$ の水銀輝線を完全に吸収 していることがわかる. 一方, 可視領域の分光ェネルギー分布 では，いずれの形のランプに拈いても開発品は通常品とほとんど 変わらないのに対して, 従来品はこの両者に比べ水銀輝線（主に $436 \mathrm{~nm}$ ) と蛍光ェネルギーの比率が異なる. 特にW-EDL 形ラン プに打いてその傾向が強い。

\section{4 紫外線の放射量}

紫外線強度計（UVR-365）を用いて, 試作ランプの紫外線の放 射量を測定した．表 2 に示すように，D形，W-DL 形拈よび WEDL 形ランプのいずれに打いても，通常品に紫外線が検出され るのに対し, 開発品括よび従来品には全く検出されない。

表 紫外線の放射量 (FL 20 S, 0 時間值)

\begin{tabular}{|c|c|c|}
\hline & 紫 外線 吸収 膜 & $\mathrm{UV}$ 放射量 $\left(\mu \mathrm{W} / \mathrm{cm}^{2}\right)$ \\
\hline D形ランプ & 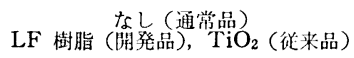 & $\begin{array}{l}5.47 \\
0.00\end{array}$ \\
\hline W-DL形ランプ & 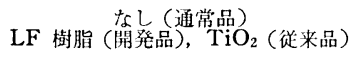 & $\begin{array}{l}4.27 \\
0.00\end{array}$ \\
\hline W-EDL形ランプ & 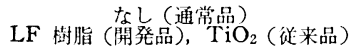 & $\begin{array}{l}0.95 \\
0.00\end{array}$ \\
\hline
\end{tabular}

\section{5 全光束および演色性}

D形, W-DL 形, および W-EDL 形の試作ランプ (FL 20 S) の測光掞よび測色を行なった結果を表 3 示す.

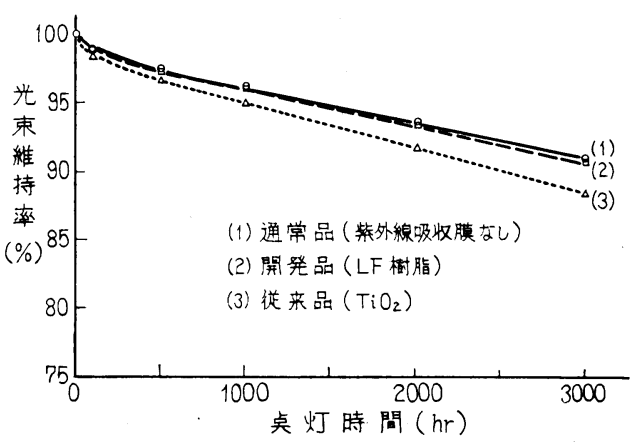

図 10 W-EDL 形ランブ (FL 20 S) の働跬特性

れは, 光束維持率の低下は蓝光体の劣化によるもので, LF 樹脂 塗膜の少化によるものではないことを表わしている．また 3,000 時間点灯後も紫外線忹全く検出されない。

一方, 従来品は 1,000 時間までは開発品と大差がないものの, それ以降は $2 \sim 3 \%$ 光束維持率に差が生ずる. これは, 酸化チタ ンが時間の経過に伴い, 少しずつ着色するためと考えられる.こ の従来品の 3,000 時間点灯後のランプ外镜に黄変が認められた.

\section{5. あとがき}

溶剂可溶形のふっ素樹脂を主成分とする塗料を, ガラス管の外 面に塗布した無柴外線学光ランプは, (1)同種の通常品（柴外線吸

表 3 陚作监光ランプの諸特性（FL 20 S, 0 時間倪）

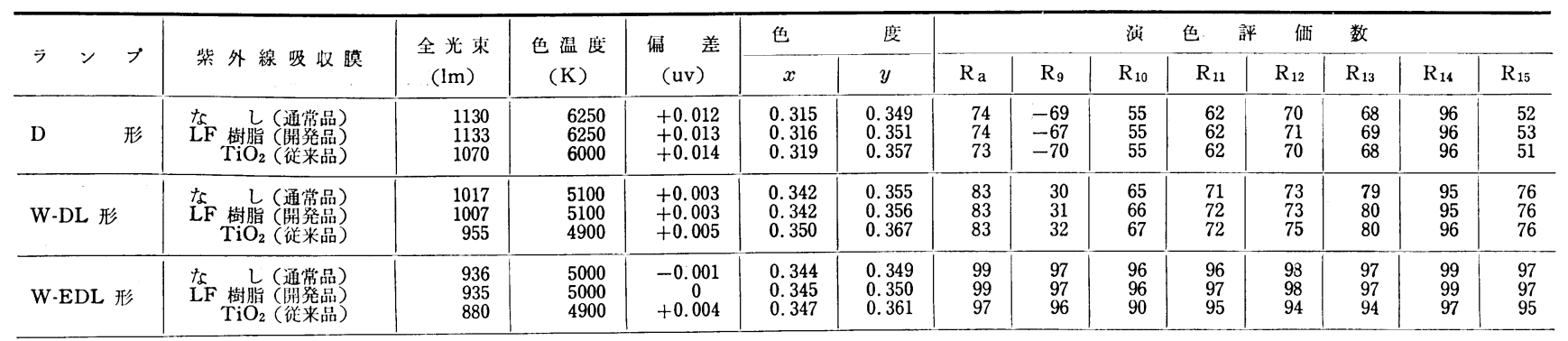

全光束はいずれの形のランプにおいても，開発品は通常品とほ とんど差がないのに対し，従来品は $5 \%$ 前後低くなっている. 次 に光色を見ると, 開発品は通常品と变わらないのに対して, 従来 品は色温度が扣よそ $200 \mathrm{~K}$ 低くなり，一方，偏差は高くなる傾向 にある. これは, 前記の分光ェネルギ一分布に抢ける従来品の挙 動（水銀輝線と蛍光エネルギーの比率が変化する）で説明ができ る.

演色評価数（ $\mathrm{R}_{\mathrm{a}}$ 打よび $\left.\mathrm{R}_{9} \sim \mathrm{R}_{15}\right)$ を見ると, 開発品は通常品 と同等な演色性を有するのに比べ, 従来品は W-DL 形に打いて は差がないものの，D形および W-EDL 形ランプにおいては， 開発品および通常品に比べ演色性が少し損なわれる.

\section{6 働 程 特 性}

上記の W-EDL 形ランプの3,000時間までの働程特性を 図 10 に示す．開発品の光束維持率は通常品と注とんど変わらない，こ
収膜なし）と同等の全光束を有し，従来品（酸化チタンを内面に 塗布したもの）に比べ抢よそ $5 \%$ 高い.(2)演色性も通常品と同等 である. (3)紫外線の吸収能力は従来品と同等である. (4) 3,000 時 間点灯後も, ガラス外面の塗膜に劣化は認められないなどの特徴 を有する.

今後, この種の蛍光ランプは需要が伸びる可能性があり, 応用 をさらに考えて行きたい。

\section{参 考 文 献}

（1）東ほか：照学誌 45-4（昭36） 145～148

(2) Anderson, H. A., Wasdyke, A. P.: Illum. Engng. 5812 (1963) $723 \sim 728$

(3) Verdu, J.: Lux 61 (1971) 36 38

(4) 小島, 山辺：有機合成化学 42-9（昭59）841 849 （受付1985年 6 月 3 日） 